\title{
THE EFFECT OF FORMOCRESOL ON HAMSTER CONNECTIVE TISSUE CELLS, A HISTOLOGIC AND QUANTITATIVE RADIOAUTOGRAPHIC STUDY WITH PROLINE-H ${ }^{3}$
}

\author{
L. H. Straffon and S. S. Han \\ Departments of Oral Biology and Pedodontics, School of Dentistry and \\ Department of Anatomy, Medical School, The University of Michigan, \\ Ann Arbor, Michigan 48104, U.S.A.
}

\begin{abstract}
Summary-The reaction to formocresol of connective tissue cells has been examined in sponge implants and femur wounds, by means of quantitative radioautography following proline- $\mathrm{H}^{3}$ injection. For twenty-four hamsters, a sponge implant on the dorsum of the neck and a surgical opening in the right femur were prepared. Formocresol was diluted to $1 / 50$ of a normal concentration for the sponge implant study and the normal concentration was tested on the femur. The time intervals from application of the drug to sacrifice were $5 \mathrm{hr}$, 1 day, 3 and 10 days, and 1 month. Proline- $\mathrm{H}^{3}$ was injected 4 or $24 \mathrm{hr}$ prior to sacrifice. Three animals were used for the scintillation counting of blood level of tritium from 2.5 min to 6 days. The tissues were fixed in Bouin's solution, embedded and sectioned in a routine manner. The sections were coated with Kodak NTB-3 emulsion and exposed for suitable lengths of time. Formocresol used in 1/50 concentration caused degeneration of cells in the immediate vicinity of the sponge implant as judged by histology and radioautographic grain counts. However, in all animals treated with formocresol a definite reduction in the number of infiltrating inflammatory cells was observed. By the tenth day both the experimental and control sponges showed a comparable recovery of the connective tissue ingrowth. This was also true for the repair in the femur wound area. It was concluded that formocresol does not interfere with prolonged recovery of connective tissue and might suppress initial inflammatory response, significantly.
\end{abstract}

\section{INTRODUCTION}

THE SOLuTION of formocresol (FC) used today, was introduced by BUCKLEY (1904) as an empirical means of pulp treatment. Prior to this and since then, different combinations of formaldehyde and cresol had been used along with arsenic to "mummify" the pulp, i.e. to fix and produce a rubbery mass of connective tissue (BONNECKER and Prinz, 1899; Bonsack, 1930; CoOlidge, 1932; Foster, 1936; Hess, 1920; LuTZ, 1923; Müller, 1920; Orban, 1933, 1934). SweET (1936) formulated a treatment regimen for the use of $\mathrm{FC}$ on exposed primary teeth and had excellent clinical results. Since this time many clinical and histological investigations have been carried out, giving variable percentages of successful FC pulpotomies (BEAVER, KOPEL and SABES, 1966; Berger, 1963; DiETZ, 1961; Doyle, 1961; EASLICK, 1939; EMMERSON et al., 1959; LAW, 1964; MansukHANI, 1959; NaCHT, 1956; Spedding, 1964; Wong, 1958).

Attempting to lcarn the ccllular and tissue cffects of FC or formaldehydc, others have studied the drug effect on the skin (BLACK, 1915; ELLIOTT and PACE, 1963; 
Grossman, 1944; Peck, 1898; Rubbo, Reich and Dixson, 1958; Schilder and AMSTERDAM, 1959), muscle (STANDISH, 1964), and bacteria (BARTELS, 1941; KITCHIN and Horton, 1931; NeELy, 1963a, b; PeAr, 1942).

Despite these attempts, the basic effects of FC on the metabolism of connective tissue cells are not clearly understood and no unified views exist on this point. The purpose of this article is to evaluate the appearance of connective tissue cells and their capacity to incorporate radioactive proline by means of quantitative radioautography, as observed in the polyvinyl alcohol sponge implants in the presence or absence of FC. A limited observation on the histologic response of the bone will also be recorded.

\section{MATERIALS AND METHODS}

\section{Experimental regimen}

A total of twenty-seven young adult golden Syrian hamsters (Mesocricetus auratus), weighing $100-130 \mathrm{~g}$, were used throughout this investigation. All animals were maintained on a stock Purina chow and tap water ad libitum.

A sponge implant on the dorsum of the neck and a surgical opening in the right femur were prepared in twenty-four hamsters. Formocresol (Buckley's Formocresol: Formaldehyde 19 per cent and cresol 35 per cent in a vehicle of glycerine 15 per cent and water. Crosby Laboratories, Burbank, California) was diluted to a $1 / 50$ of a normal concentration for the sponge implant study. The wound placed in the femur received a normal concentration of formocresol. Physiologic saline was used as a control.

The intervals from the application of the drug to sacrifice were $5 \mathrm{hr}, 1$ day, 3 and 10 days, and one month. The injection time of radioactive proline with respect to that of sacrifice was 4 and $24 \mathrm{hr}$. Twelve animals were used for experiments and 12 for controls. Three animals were used for the scintillation counting of the blood level of $\mathrm{H}^{3}$ as a function of time.

\section{Surgical procedure}

The hamsters were anaesthetized by an intraperitoneal injection of: nembutal, U.S.P., $1.0 \mathrm{ml}$; distilled water, $4.5 \mathrm{ml}$. For every $10 \mathrm{~g}$ of body weight, $0.05 \mathrm{ml}$ of the above anaesthetic was injected. To maintain the anaesthesia, half of the initial dose was repeated.

The dorsal skin just posterior to the neck was shaved. A midline incision was made through the epidermis for about $3 \mathrm{~mm}$, and a previously sterilized polyvinyl alcohol sponge measuring $5 \mathrm{~mm}$ in diameter was implanted. Metal clips were used as sutures. Throughout the procedure care was taken to maintain general principles of sterile surgical techniques.

Concurrently with the implantation of sponge, the right hind leg was shaved and an incision made into the skin for $20 \mathrm{~mm}$. Blunt longitudinal dissection of the muscles was performed along the lateral intermuscular septum to expose the lower part of the femur, and approximately $3 \mathrm{~mm}$ of periosteum was removed. With a dental handpiece at $10,000 \mathrm{rev} / \mathrm{min}$, a round carbide bur, No. 1/2, was used to bore 
a hole into the femur. A sterile cotton pellet moistened with saline was used to wipe the area clean of debris. A medium-size paper point was dipped in the drug and applied into the open wound for $5 \mathrm{~min}$. After the paper point was removed, the incision was sutured with metal clips.

\section{Injection of radioisotope and scintillation counting}

Tritiated L-Proline-3, 4- $\mathrm{H}^{3}$ (specific activity $5 \cdot 0 \mathrm{c} / \mathrm{mM}$ ), obtained from New England Nuclear Corp., was the radioactive precursor administered. This will be referred to as proline- $\mathrm{H}^{3}$. The isotope was used in the amount of $5 \mu \mathrm{c} / \mathrm{g}$ body weight.

In order to determine the blood level of available radioactive precursors, three hamsters were injected with the same relative amounts of proline- $\mathrm{H}^{3}$ and bled at: $2 \cdot 5,5,10,20,30,40,50$ and $60 \mathrm{~min}, 6,12,18,24,30,36,42$ and $48 \mathrm{hr}$, and 4 and 6 days after injection (ANDERSON, 1965).

Blood samples, approximately $0.008 \mathrm{ml} /$ animal, were collected in heparinized capillary tubes measuring $1.15 \mathrm{~mm} \times 75 \mathrm{~mm}$ in inner diameter and length, respectively. Blood was drawn from the choriod plexus of the eye by applying simultaneously a gentle pressure coupled with a rotary motion. The capillary tube of blood was immediately inverted into the counting vial for drainage. Then 4 drops of 30 per cent peroxide were added to cover the blood sample, which was allowed to settle for 30 min. Hyamine X-10 was added in the amount of $0.5 \mathrm{ml}$ and the vial was placed in a water bath for $30 \mathrm{~min}$ at $50-60^{\circ} \mathrm{C}$. The vial was removed, allowed to cool and then $10 \mathrm{ml}$ of the scintillation fluid was added and shaken to eliminate bubbles. Samples were stored in a refrigerator and counted a week later (FRENKEL et al., 1962; GoRDON and WOLFE, 1960; NASJLETI, 1965, personal communication).

Scintillation counting was carried out in a Packard Tri-Carb Liquid Scintillation Spectrometer, model 3000 . The mean background count was $24 \cdot 4$ counts $/$ min. The counting efficiency of the prepared system was 10 per cent.

\section{Histologic and radioautographic preparations}

The tissues were fixed in Bouin's fixative for $48 \mathrm{hr}$, washed overnight in running water and femurs were decalcified in the usual manner using Versene. They were then vacuum embedded in paraplast. Serial sections of the sponge implant at $6 \mu$ and longitudinal serial sections of femur at $10 \mu$ were made on a rotary microtome. The sections were mounted on slides which were pretreated with a subbing solution, composed of $0.5 \mathrm{~g}$ of gelatin and $0.05 \mathrm{~g}$ of chromium potassium sulphate in $100 \mathrm{ml}$ of distilled water.

For radioautography, selected slides were freed from paraplast, hydrated and dipped into Kodak NTB-3 nuclear track emulsion in a routine manner (SMrTH and HaN, 1967). Slides were placed on end and allowed to dry for $\frac{1}{2} \mathrm{hr}$. The slides were then arranged in an air-tight slide box containing small packs of Drierite, shielded with lead-sheets and kept in a refrigerator. Following 4-8 weeks of exposure, the slides were removed, developed in Dolmi solution and stained with haematoxylin and eosin. 
Slides not coated with the emulsion were stained either with haematoxylin and eosin, Masson's trichrome or PAS-azure II.

\section{RESULTS AND OBSERVATIONS}

\section{Scintillation counting}

Figure 27 records the average values of scintillation counts of the blood level of tritium obtained from three separate animals at various times following the injection of proline- $\mathrm{H}^{3}$ intraperitoneally. The vertical bars indicate the range in which the three counts fall. The level of tritium in the circulating blood rises rather rapidly during the early post-injection period, reaching a peak which diminishes gradually throughout the first week. It might be pointed out that there was about 15 per cent or more reduction in the scintillation count for 6-24 hr, a factor which should be considered in the evaluation of the grain counts.

\section{Histological observations}

After $5 \mathrm{hr}$ of implantation, the sponge from the control hamster showed a large number of polymorphonuclear leucocytes (PMN) along with some regressive changes of the surrounding connective tissue (Figs. 1 and 3). Degenerative changes were characterized by the disorganization of connective tissue fibres in the immediate vicinity of the implant. PMN were more numerous in the perivascular region, and many of them reached the surface of the sponge. On the other hand, the sponge treated with FC showed much less PMN infiltration as compared to the control (Figs. 1-4). However, signs of the connective tissue degeneration were somewhat greater.

The sponge from the 1-day control animal demonstrated again a larger number of PMN than in the experimental hamster (Figs. 5-8). Many of the PMN were degranulated and could be identified only on the basis of the nuclear morphology. Occasional mononuclear cells appeared at this time, some of which appeared to be hypertrophic and actively phagocytizing the nuclear debris of PMN (arrow, Fig. 7). The fibroblasts located along the periphery of the control sponge demonstrated a cytoplasm which was highly basophilic and contained a large nucleus with prominent nucleoli. In the experimental animals these changes did not appear to take place as fast as in the control (Fig. 8). Although there was a migration of mononuclear cells, they werc few in number and connective tissue fibres remained as broken patches of homogeneous eosinophilic material. Few active fibroblasts were observed.

By the end of 3 days a greater number of active fibroblasts and newly developing connective tissue fibres were observed along the surface of the control sponge (Fig. 9). The connective tissue covering the sponge from the experimental animal also contained numerous active fibroblasts infiltrating the area (Fig. 10). At the outer border of the sponge, typical giant cells were seen along with phagocytic macrophages in the control animal, while no giant cells were observed in the FC-treated sponge.

On the tenth day the control sponge showed few PMN and the ingrowth of connective tissue was well advanced (Figs. 11 and 13). Similar changes had occurred in the 
experimental animal by this time. However, the ingrowth of the tissue into the substance of the matrix might have been somewhat less than in the control (Figs. 11 and 12). Within the sponge matrix of the control there was finely fibrous material, while in the experimental such network of fibrous material was even finer. Along the trabecular surface of the sponge in the experimental animal was found a fair number of large giant cells with basophilic cytoplasm (Fig. 14). After 31 days, the capsule of the connective tissue in both experimental and control animals was well organized and the intra-trabecular space of both sponges was filled with advancing connective tissue elements along with giant cells and a number of macrophages.

Histologically, events occurring in the femur more or less paralleled the general changes which were characteristic of the connective tissue of the sponge implants. Thus, the wound region of the femur treated with FC had a smaller number of PMN infiltrating the haemorrhagic mass than the control. On the third day the marrow space adjacent to the haematoma of the wound region showed many macrophages containing haemosiderin and the infiltration of capillaries and fibroblast-like cells in both groups, although the number of fibroblasts was greater in the control. Of significance was the observation that both the control and experimental animals presented a similar histological picture 10 days after surgery (Figs. 15 and 16). The degenerating tissues were replaced by active fibroblasts and connective tissue fibres and new bone formation was clearly evident in both groups. In the control the amount of newly formed bone was slightly greater than in the FC-treated femur. No difference between the two could be distinguished 31 days after the injury.

With the PAS-azure II stain, there was a greater number of mast cells in the immediate vicinity of the experimental sponge implant at 5 and $24 \mathrm{hr}$ than in the control. At $24 \mathrm{hr}$, the mast cells next to the sponge in the experimental animal were degranulated and fewer in number than in the control. By the third day, the mast cells in the experimental animal were still in greater number than the control, but at 10 days and 1 month, the number was about equal.

\section{Radioautography; grain counts of the sponge}

Grain counts were made in at least 100 individual fibroblasts of sponge implants representing each period. Since many cells of the FC-treated sponge were entirely free of overlaying silver grains during the early post-operative period, the average grain counts of labelled cells might not be a valid expression of the total activity of the fibroblast population. Hence, the percentage of unlabelled fibroblasts was studied by counting 100 cells in a randomly selected field at the periphery of the sponge. The results showed that after $5 \mathrm{hr}$ about 40 per cent of the fibroblasts were unlabelled in the experimental animals whereas the percentage of the unlabelled cells of the control was 12 per cent (Figs. 17 and 18). One day after implantation, the experimental hamster showed 16 per cent of the fibroblasts unlabelled and all of the cells in the control showed labelling of varying degrees. By the third day all of the fibroblasts in both groups were labelled (Figs. 19 and 20).

W In view of this difference the quantitative evaluations of silver grains recorded in Figs. 28 and 29 were obtained from counting only the labelled fibroblasts throughout 
the experimental period. It might be noted that the patterns of histograms representing $4 \mathrm{hr}$ and $24 \mathrm{hr}$ after proline- $\mathrm{H}^{3}$ are similar to each other, except that generally lower values and less significant differences are shown in the 24-hr post-injection group. The average number of grains/control fibroblast is significant $5 \mathrm{hr}$ after the sponge implantation, appears to reach a peak between 1 and 3 days after the implantation, and is followed by a gradual reduction thereafter. The FC-treated group shows only a minimal labelling $5 \mathrm{hr}$ after the implantation of the sponge, but the labelling rises rapidly within a day. However, the grain number/experimental fibroblast during the first few days is never as high as that of the control.

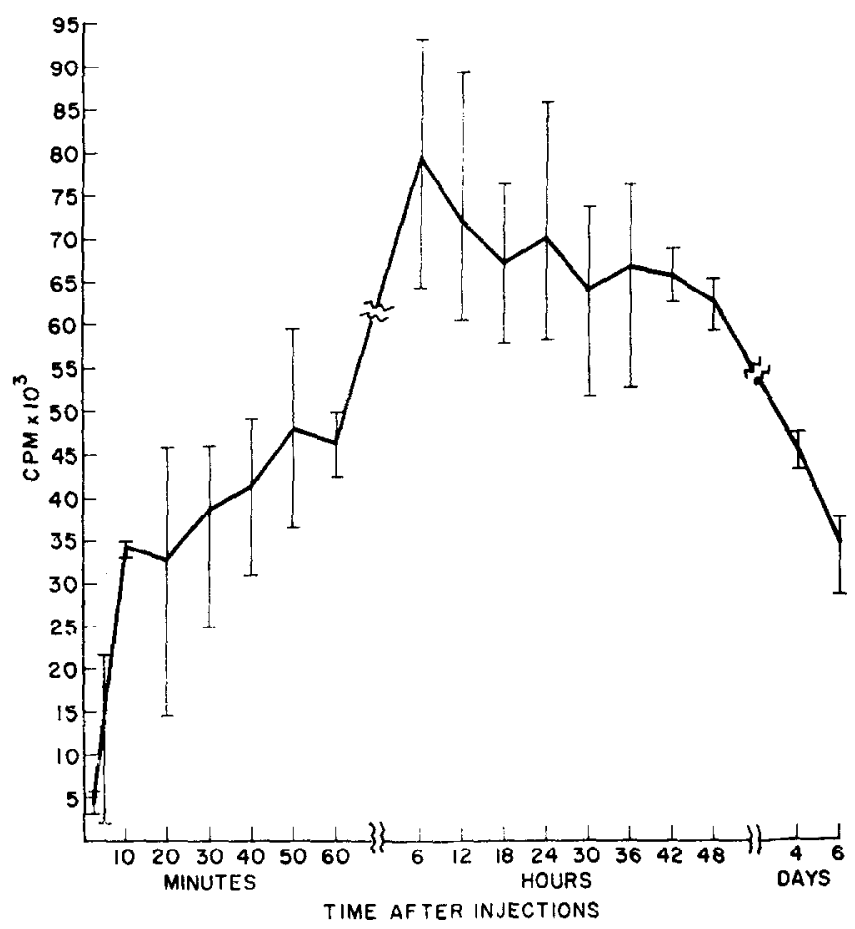

Fig. 27. The level of total tritium activity in whole blood of three adult hamsters.

The relative number of extracellularly located grains in samples taken $24 \mathrm{hr}$ after the injection of radioactive precursor shows changes that tend to amplify the results of grain counting (Figs. 21-26). A greater number of extracellular grains may be noted in the control as early as 1 day after implantation of the sponge (Figs. 21 and 22). The maximum difference was expressed in sponges taken 3 days after the implantation (Figs. 23 and 24). By day 10 and 1 month such difference could not be observed (Figs. 25 and 26). 


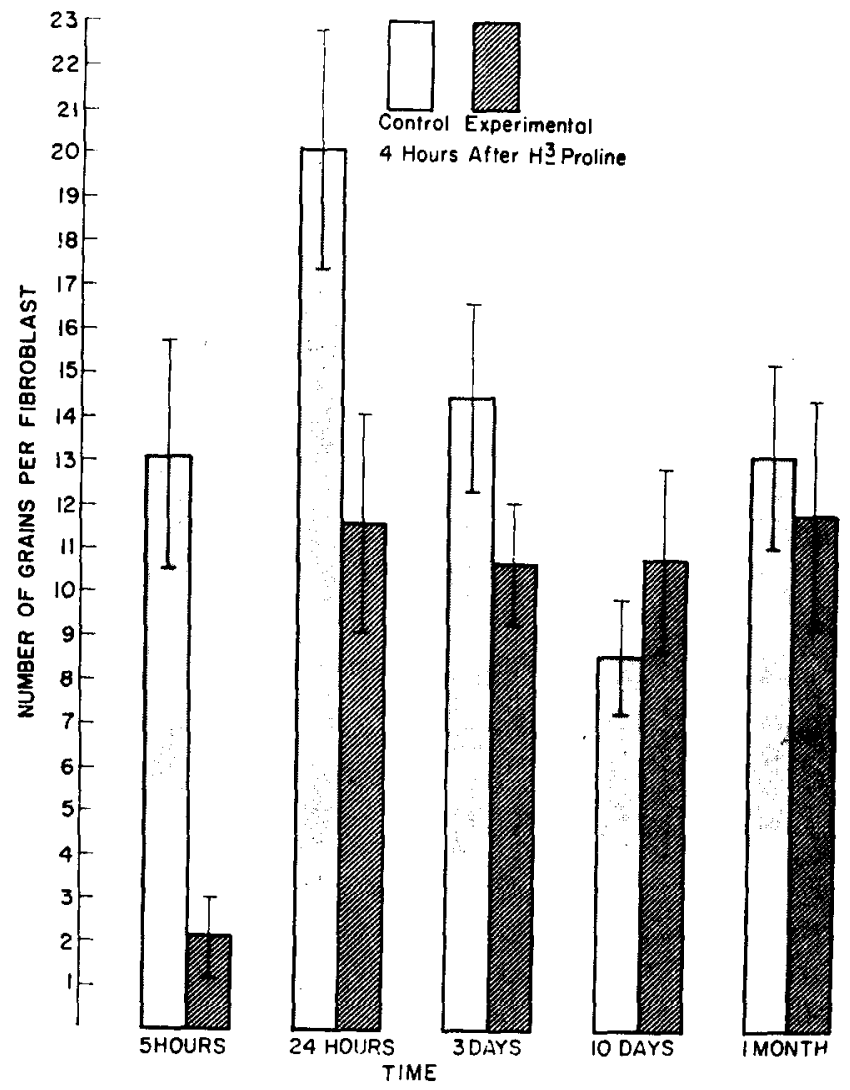

FiG. 28. The average number of grains per fibroblast, $4 \mathrm{hr}$ after $\mathbf{H}^{3}$-proline injection in the control and experimental hamsters at 5 and $24 \mathrm{hr}, 3$ and 10 days, and 1 month. The range indicates standard deviation. 

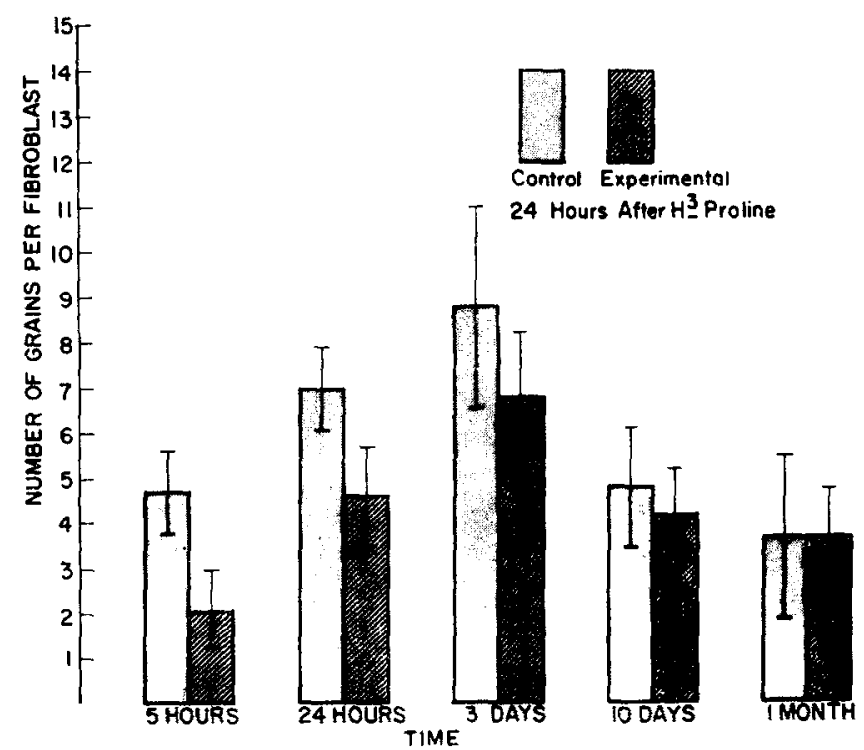

Fig. 29. The average number of grains/fibroblast, $24 \mathrm{hr}$ after proline- $\mathrm{H}^{3}$ injection in the control and experimental hamsters at 5 and $24 \mathrm{hr}, 3$ and 10 days, and 1 month. The range indicates standard deviation.

\section{DISCUSSION}

Aside from the generally accepted effects of pulp "mummification", the mechanism of FC action on the connective tissue cells has not been clarified to a satisfactory extent. It has been shown that one of the components of $\mathrm{FC}$, the formaldehyde, reacts with $\mathrm{NH}_{2}$ group of certain amino acids and creates a methylene bridge linking protein chains together; for example, lysine to lysine or from lysine to glutamine (BAKER, 1960; De Robertis, Nowinski and SAEG, 1965; DobBs, 1961; Lillie, 1965; SollmanN, 1957; Wolman, 1955). Fraenkel-Conrat (1954) and Staehelin (1958) have reported that the inactivation of the tobacco mosaic virus by formaldehyde is due to its interaction with the amino group of adenine, cytosine and guanine in the ribonucleic acid moiety. They also reported that DNA did not react with formaldehyde under the same conditions. HASELKORN and DOTY (1961) have further elaborated upon this and stated that the reaction of formaldehyde with polynucleotides is first a denaturation step, then the reaction of formaldehyde with freed amino groups occurs.

With respect to the tricresol, which is the other major component of FC, a review of the literature indicates that its specific action at the cellular level has not been determined. The toxicity of cresol is said in standard text books to be less than that of the phenol, although the opposite has been reported (DoBBS, 1961; FrancIS and Wood, 1961; Krantz and Carr, 1954; PafF, Lehman and Halperin, 1945; SOLLMANN, 1957). ZANDER and GLASs (1949) stated that phenol placed prior to capping of the exposed dental pulp did not interfere with nor enhance the healing process. 
The result of the present study strongly indicates that the FC used in 1/50 of the normal concentration still causes an effective fixation of cells in the immediate vicinity of the sponge implant around which the ingrowth of the connective tissue begins. Such cytotoxic effect is evidenced by the fact that 40 per cent of the cells in the immediate vicinity are not labelled during the early post-operative period. In this connection it is of a fundamental and clinical importance that the connective tissues around the FC-treated sponge showed far fewer inflammatory cells as compared to the control sponge. It indicates that the cytotoxic effect of FC used at this concentration might have been enough to modify changes in the capillary permeability as well as the leukocytic migration which normally occurs in the immediate vicinity of implanted sponge (HAN and AVERY, 1964). In addition to the few PMN observed, the number of infiltrating mononuclears on day 1 was also smaller in the experimental animal, and the appearance of giant cells was delayed. Thus, the histological appearance of the sponge and the connective tissue in its immediate vicinity indicates that the FC-treated sponge might have effectively reduced the inflammatory response of the region. Of further interest is the fact that by the tenth day both the experimental and control sponges showed a comparable recovery in the pattern of connective tissue ingrowth and in the number of silver grains over fibroblasts. This is further supported by the observation that, even in the femur which was treated with the full concentration of FC, the repair of the bone in the surgical lesion had progressed considerably by the tenth day of the experiment.

The radioautographic studies of fibroblast activity following the administration of proline- $\mathrm{H}^{3}$ have been done by numerous authors under different conditions. HAN, AVERY and BANG (1967), in studying the dental pulp fibroblast following actinomycin $\mathrm{D}$ administration, have established a correlation between the regressive changes occurring in the cytoplasmic ultrastructure and the amount of proline- $\mathrm{H}^{3}$ taken up by the fibroblasts as judged by the appearance and the number of silver grains overlaying fibroblasts. It appears, therefore, reasonable to presume that the significant reduction of grain numbers in experimental animals during the first 3 days of study might be taken as evidence for damage incurred in the cytoplasmic structure of the fibroblasts in the region with respect to their protein synthetic capacity.

The increase of the number of grains in the control animals at different times, which appear to be highest somewhere between 1-3 days, might reflect the increased function of average fibroblasts in the growing connective tissue and thus support histological observations in which the fibroblasts appeared more robust during this period. The differences between control animals sacrificed $4 \mathrm{hr}$ and $24 \mathrm{hr}$ after the proline- $\mathrm{H}^{3}$ injection could be partially due to differences in the level of available precursors in the blood. It is more likely that the differences are due to the way in which the grain counts were made. Since the cell boundary in fibroblasts was not distinct and often difficult to recognize, only those grains that were clearly inside the cell were counted and the grains that were present along the surface were considered extracellular and not counted.

The cytotoxicity of FC even at the concentration of $1 / 50$ of that of the $\mathrm{FC}$ in normal use is evidenced by the large percentage of unlabelled fibroblasts in animals 
sacrificed shortly after the application of the drug. On the other hand, that there was no significant difference between experimental and control groups after 10 days of experiment further strengthens the conclusion that the FC effect is limited to the first 10 days of the experiment.

While histologic examination of the femurs suggests that a satisfactory recovery can be achieved shortly after treatment with FC of full strength, a further study of the relative effects of various $\mathrm{FC}$ concentrations on the metabolism of connective tissue cells will be of significance. In the meantime, our observations can be taken as evidence for the fact that FC kills a large number of cells as well as degrading physiological activities of surviving cells in the vicinity even at a fairly low concentration. As the result of such cytotoxic and cytostatic effects, the connective tissue of FC-treated animals could maintain a relatively inflammation-free status which is followed by a normal recovery within the first month. Such a freedom from inflammation might be a beneficial aspect of FC-treatment in tissues such as dental pulp, where an inflammatory response subsequent to pulpotomy could create a serious clinical complication whereas the tooth might be able to withstand the temporary slowdown of the recovery process without manifesting any clinical sign.

Acknowledgement-This study was supported by grants from the Le Gro Fund of the University of Michigan School of Dentistry and U.S.P.H.S. DE-01620, DE-02311, DE-02731 and HD-03147.

Résumé-La réaction cellulaire conjonctive envers le formocrésol a été étudiée au niveau d'éponges implantées et dans des pertes de substance du fémur, à l'aide de radioautographies quantitatives, après injection de proline- $\mathrm{H}^{3}$. Une éponge est implantée dans le dos de la nuque et une cavité est préparée chirurgicalement dans le fémur droit de 24 hamsters. Le formocrésol est dilué au 1/50ème pour l'étude utilisant des éponges: une concentration normale est implantée dans le fémur. L'intervalle de temps entre l'application médicamenteuse et le sacrifice est de 5 heures, 1 jour, 3 et 10 jours et un mois. La proline- $\mathrm{H}^{3}$ est injectée 4 à 24 heures avant le sacrifice. Trois animaux ont été utilisés pour déterminer, au scintillateur, le taux sanguin de tritium de 2,5 min-6 jours. Les tissus sont fixés dans la solution de Bouin, inclus puis coupés. Une émulsion Kodak NTB-3 est utilisée pour l'autoradiographie. Le formocrésol à 1/50ème provoque une dégénérescence cellulaire au voisinage immédiat de l'implant-éponge. Cependant, dans tous les animaux traités par le formocrésol, une réduction marquée des cellules inflammatoires est observée. Au 10ème jour, les éponges expérimentales et contrôles montrent des stades similaires. Ce fait est également valable pour la cicatrisation observée au niveau du fémur. Il semble que le formocrésol n'empêche pas la cicatrisation conjonctive, tout en supprimant significativement la réponse inflammatoire initiale.

Zusammenfassung-Mit Hilfe quantitativer Autoradiographie nach Prolin- $\mathrm{H}^{3}$-Injektion wurde der Einfluß von Formokresol auf Bindegewebszellen in Schwammimplantaten und Femurwunden untersucht. Bei 24 Hamstern wurde im Nackenrücken ein Schwamm implantiert und der rechte Femur chirurgisch eröffnet. Für den Versuch mit Schwammimplantaten wurde Formokresol auf 1/50 der normalen Konzentration verdünnt, während am Femur die normale Konzentration getestet wurde. Die Zeitintervalle von der Anwendung des Pharmakons bis zur Tötung betrugen 5 Stunden, 1, 3 und 10 Tage sowie 1 Monat. $\mathrm{H}^{3}$-Prolin wurde 4 oder 24 Stunden vor der Tötung injiziert. 3 Tiere wurden dazu verwendet, den Tritiumspiegel im Blut von 2,5 min bis 6 zu Tagen nit Hilfe der Scintiallationszählung zu bestimmen. Die Gewebe wurden in Bouin's-Lösung fixiert, und in üblicher Weise eingebettet und geschnitten. Die Schnitte wurden mit 
Kodak-NTB-3 Filmen bedeckt und ausreichend lange exponiert. Formokresol in 1/50 Konzentration verursachte in der unmittelbaren Umgebung des Schwammimplantates Zelldegeneration, wie histologisch und durch autoradiographische Kornzählungen nachweisbar war. Bei allen mit Formokresol behandelten Tieren wurde jedoch eine deutliche Reduktion der Anzahl infiltrierender Entzündungszellen beobachtet. Um den zehnten Tag herum zeigten sowohl die Versuchs- als auch die Kontrollschwämme einen vergleichbaren Stand des einwachsenden Bindegewebes. Dies traf auch für die Heilung der Femurwunde zu. Daraus wurde geschlossen, daß Formokresol die verzögerte Wiederherstellung des Bindegewebes nicht stört und zugleich initiale Entzündungsreaktionen signifikant herabzudrücken vermag.

\section{REFERENCES}

ANDERson, A. A. 1965. The protein matrices of the teeth and periodontium in hamsters-a tritiated proline study. M. Sc. Thesis, Univ. Michigan, p. 84.

BAKER, J. R. 1960. Cytological Technique (4th ed.), p. 150. Wiley, New York.

BARTELS, H. A. 1941. A bacteriologic appraisal of some material used in root-canal therapy. $J . A m$. dent. Ass. 28, 1108-1112.

Beaver, H. A., Kopel, H. M. and Sabes, W. R. 1966. The effect of zinc oxide-eugenol cement on a formocresolized pulp. J. dent. Child. 33, 381-396.

BERGER, J. E. 1963. An evaluation of the effects of formocresol on the pulps of human primary molars following pulpotomies. M. Sc. Thesis, Univ. Michigan, p. 92.

BLack, G. V. 1915. Special Dental Pathology, p. 489. Medico-Dental, Chicago.

BonNeCKer, and Prinz, H. (translator). 1899. Modern methods of treatment of diseased pulps. Ohio dent. J., Toledo. 19, 183-184.

BonsaCK, C. 1930. Technique of mummification with the trio paste of Prof. Gysi. Dent. Items 52, $681-685$.

Buckley, J. P. 1904. A rational treatment for putrescent pulps. Dent. Rev. 18, 1193-1197.

COOLIDGE, E. D. 1932. Reaction of dog tissue to drugs used in root canal treatment. J. Am. dent. Ass. $19,747-759$.

De Robertis, E. D. P., Nowinski, W. W. and SAEG, F. A. 1965. Cell Biology (4th ed.), p. 446. Saunders, Philadelphia.

DiETz, D. R. 1961. A histologic study of the effects of formocresol on normal primary pulpal tissue. M. Sc. Thesis, Univ. Washington, p. 55.

Dosis, E. C. 1961. Pharmacology and Oral Therapeutics (12th ed.), p. 578. Mosby, St. Louis.

Doyle, W. A. 1961. A comparison of the formocresol pulpotomy technique with the calcium hydroxide pulpotomy technique. M. Sc. Thesis, Indiana Univ., p. 68.

EasLick, K. A. 1939. Pulp management for deciduous and young permanent teeth. J. Am. dent. Ass. 26, $100-112$.

ElliotT, A. and PACE, D. M. 1963. Observations on the effects of methanol and formaldehyde on established cell lines cultivated in vitro. Can. J. Biochem. Physiol. 41, 299-304.

Emmerson, C. C., Miyamoto, O., Sweet, C. A., Sr. and Bhatia, H. L. 1959. Pulpal changes following formolcresol applications on rat molars and human primary teeth. J. sth Calif. St. dent. Ass. 27, 309-323.

Foster, H. R. 1936. The pulpless deciduous teeth. J. Am. dent. Ass. 23, 2057-2065.

Fraenkel-ConRat, H. 1954. Reaction of nucleic acid with formaldehyde. Biochem. biophys. Acta 15, 307-309.

Francis, L. E. and Woon, D. R. 1961. Dental Pharmacology and Therapeutics, p. 288. Saunders, Philadelphia.

Frenkel, E. P., Whalley, B. E., KnorpP, C. T. and Korst, D. R. 1962. On the counting of tritiated thymidine in tissues. J. Lab. clin. Med. 59, 174-178.

Gordon, C. F. and WolFe, A. L. 1960. Liquid scintillation counting of aqueous samples. Analyt. Chem. 32, 574.

Grossman, L. I. 1944. Irritating potentialities of root canal medicaments. Am. J. Orthod. 30, 564-566.

HAN, S. S. and AVERY, J. K. 1964. Light and electron microscopic observation of connective tissue growing into sponge implants. J. dent. Res. 43, 852, (Abstract). 
HAN, S. S., AVERY, J. K. and BANG, J. S. 1967. The effect of actinomycin D on the fibroblast of the pulp of the rat incisor-A study by quantitative radioautography and electron microscopy. Archs oral Biol. 12, 503-512.

HASELKORN, R. and DoTY, P. 1961. The reaction of formaldehyde with polynucleotides. J. biol. Chem. 236, 2738-2745.

HEss, W. 1920. Klinisch-bakteriologische Untersuchungen uber die Wirkung der Triopaste auf die Gangraena Pulpae. Schweiz. Vischr. Zahnheilk. 30, 1-37.

Kitchin, P. C. and HORTON, B. T. 1931. The relative efficiency from a bacteriologic standpoint of some materials used in the treatment of putrescent root canals. J. Am. dent. Ass. 18, 1668-1685.

Krantz, J. C. and Carr, C. J. 1954. Pharmacologic Principles of Medical Practice (3rd ed.), p. 1183. Williams and Wilkins, Baltimore.

LAw, D. B. and LEwis, T. M. 1964. Formocresol pulpotomy in deciduous teeth. J. Am. dent. Ass. 69, 601-607.

LILLIE, R. D. 1965. Histopathologic Technic and Practical Histochemistry (3rd ed.), p. 715. McGrawHill, New York.

LUTZ, K. 1923. Histologische und bakteriologische Untersuchungen über die Wirkung der Triopaste bei der Pulpa-amputation. Schweiz. Mschr. Zahnheilk. 33, 81-121.

Mansukhani, N. 1959. Pulpal reactions to formocresol. M. Sc. Thesis, Univ. Illinois, p. 80.

MÜLlER, O. 1920. Histologische und bakteriologische Befunde nach Pulpa-amputation. Schweiz. Vischr. Zahnheilk. 30, 38-46.

NACHT, M. 1956 A. devitalizing technic for pulpotomy in primary molars. J. dent. Child. 23, $45-47$.

NEELY, W. B. 1963a. Action of formaldehyde on micro-organisms. I. Correlation of activity with formaldehyde metabolism. J. Bact. 85, 1028-1031.

NeELY, W. B. 1963b. Action of formaldehyde on micro-organisms. III. Bactericidal action of sublethal concentrations of formaldehyde on Aerobacter aerogenes. J. Bact. 86, 445-448.

Orban, B. 1933. Action of paraformaldehyde on dental pulp. J. dent. Res. 13, 215.

Orban, B. 1934. Metaplastic changes in pulp due to large doses of paraformaldehyde. J. dent. Res. 14, 189.

PAfF, G. H., Lehman, R. A. and Halperin, J. P. 1945. Comparison of the toxicity of antiseptics for embryonic tissue and bacteria. Proc. Soc. exp. Biol. Med. 58, 323-326.

Pear, J. 1942. Bactericidal effects of some drugs used in pulp canal therapy. J. Am. dent. Ass. 29, 244-248.

PECK, A. H. 1898. The essential oils and some other agents, their antiseptic value, also their irritation or nonirritating properties. Dent. Rev. Chicago 12, 593-608.

Rubbo, S. D., Reicir, J. and Dixson, S. 1958. The use of a combination of neomycin, bacitracin, and polymyxin in endodontia. Oral Surg. 11, 878-896.

SCHILDER, H. and AMSTERDAM, M. 1959. Inflammatory potential of root canal medicaments. Oral Surg. 12, 211-221.

SMTT, D. M. and HAN, S. S. 1967. A quantitative radioautographic study of the effect of anoxic stress on $\mathbf{H}^{3}$-proline incorporation by oral connective tissue cells in the hamster neonate. Submitted for publication.

Sollmann, T. H. 1957. A Manual of Pharmacology (8th ed.), p. 1535. Saunders, Philadelphia.

SPEDDING, R. H. 1964. The effect of formocresol and calcium hydroxide on the dental pulps of Rhesus monkeys. Ind. Univ. School Dent. Alumni Bul. Spring issue.

Staehelin, M. 1958. Reaction of tobacco mosaic virus nucleic acid with formaldehyde. Biochem. biophys. Acta 29, 410-417.

Standish, S. M. 1964. Striated muscle regeneration after chemical injury. Archs Path. 77, 330-339.

SweET, C. A. 1936. Treatment for deciduous teeth with exposed pulps. Texas dent. J. 54, 6. (May, No. 5).

TORNECK, C. D. 1959. The reaction of hamster tissue to drugs used in the sterilization of the root canal. M.Sc. Thesis, Univ. Michigan, p. 49.

Wolman, M. 1955. Problems of fixation in cytology, histology, and histochemistry. In: International Review of Cytology (Edited by BourNe, G. H. and Danielu, J. F.), p. 419. Vol. IV. Academic Press, New York.

WoNG, KA-CHOI. 1958. Effects of paraformaldehyde preparations on the periapical tissues in nonvital pulpotomy procedures. M.Sc. Thesis, Northwestern Univ., p. 122.

Zander, H. A. and Glass, R. L. 1949. The healing of phenolized pulp exposures. Oral Surg. 2, 803-810. 
Plates 1-5 overleaf 
Plate 1

FIG. 1. Control sponge, $5 \mathrm{hr}$ after implantation. Many PMN are located in the blood vessels and tissue. Haematoxylin and eosin. $\times 85$.

FIG. 2. The sponge from experimental animal, $5 \mathrm{hr}$ after implantation. Few PMN are found in the tissue. Haematoxylin and eosin. $\times 85$.

FIG. 3. Five hr after the sponge implant the control animal has an influx of PMN. Haematoxylin and eosin. $\times 538$.

Fig. 4. The experimental animal, $5 \mathrm{hr}$ after sponge implant, has only a few PMN in the tissue. Haematoxylin and eosin. $\times 538$. 
L. H. Straffon and S. S. Han

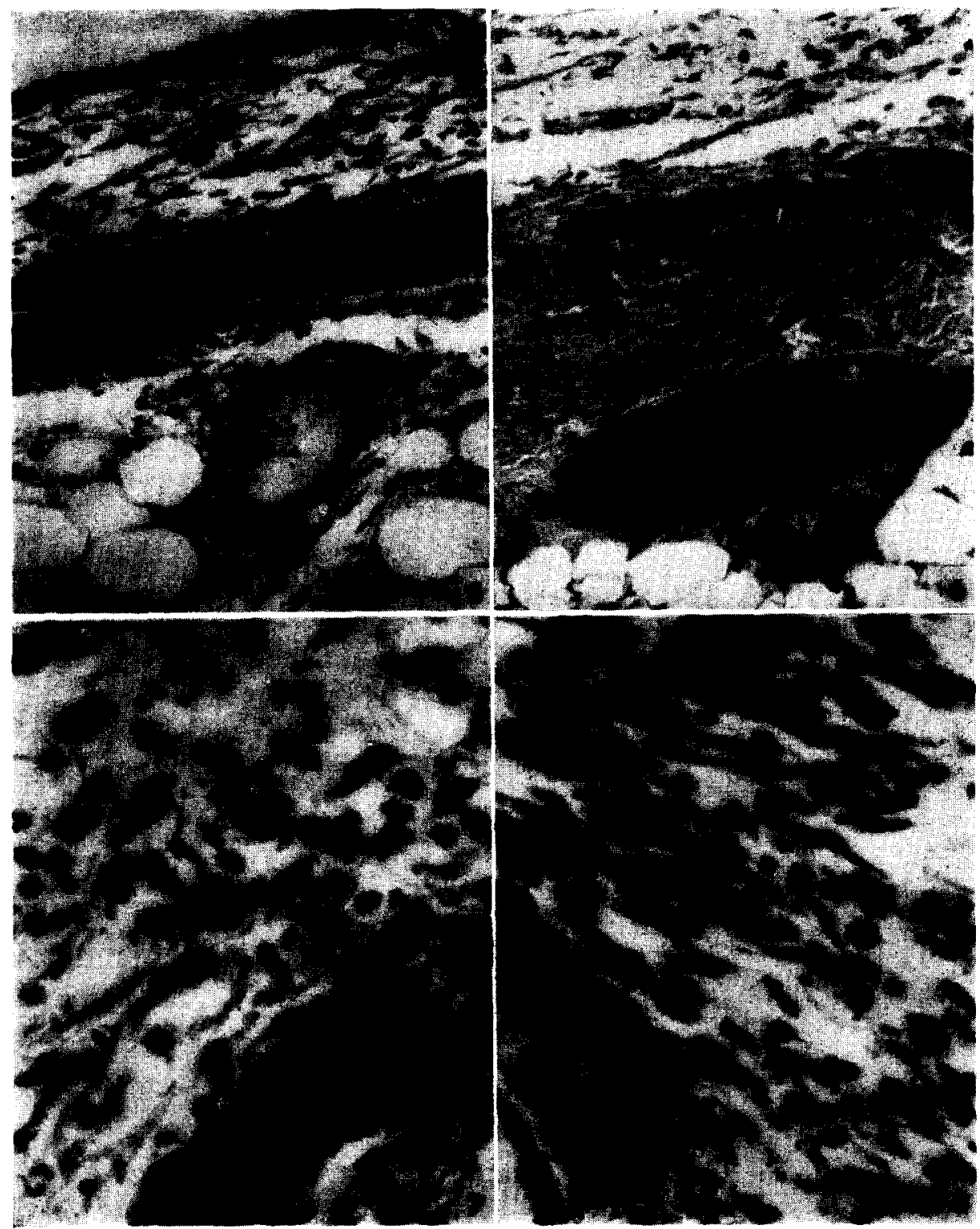

Plate 2 


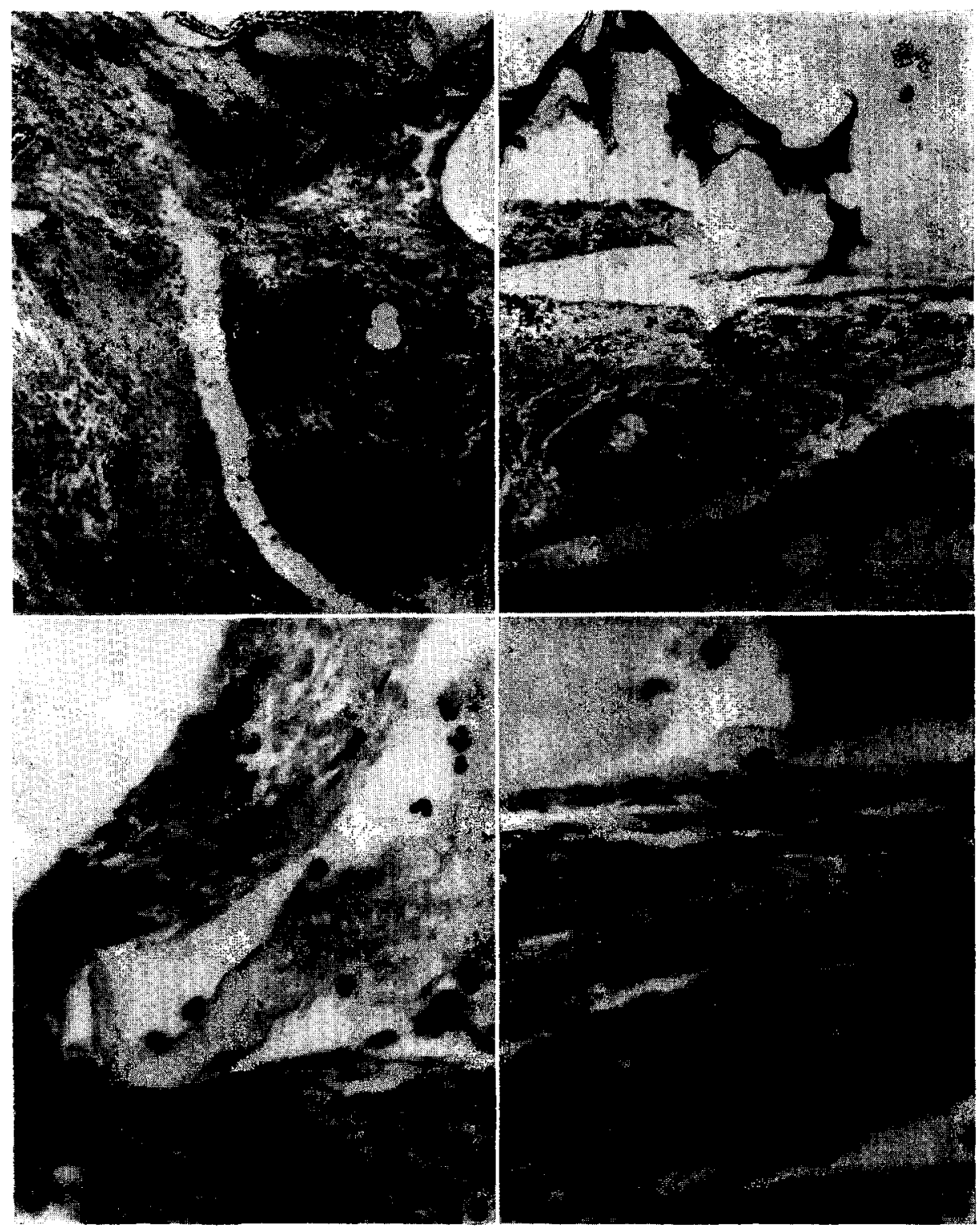

Plate 1

A.O.B. f.p. 284 


\section{Plate 2}

FIG. 5. The control sponge, $24 \mathrm{hr}$ after implantation, depicts infiltration of new PMN from the dilated vessel. Haematoxylin and eosin. $\times 215$.

FIG. 6. The sponge from experimental animal, $24 \mathrm{hr}$ after implantation has few PMN in the tissue. Haematoxylin and eosin. $\times 215$.

Fig. 7. The control animal, $24 \mathrm{hr}$ after sponge implant, has many PMN, fibroblasts and mononuclear cells. Haematoxylin and eosin. $\times 538$.

FIG. 8. The experimental animal, $24 \mathrm{hr}$ after the sponge implant has fewer PMN and mononuclears. The nuclei of fibroblasts appear denser. Haematoxylin and eosin. $\times 538$. 


\section{Plate 3}

Fig. 9. The control sponge, 3 days after implantation shows robust fibroblasts and a giant cell. Haematoxylin and eosin. $\times 538$.

FIG. 10. The sponge from experimental animal, 3 days after implantation has fibroblasts and mononuclear cells. Haematoxylin and eosin. $\times 538$.

Fig. 11. The control animal, 10 days after sponge implant has ingrowth of connective tissue. Haematoxylin and eosin. $\times 85$.

Fig. 12. Ten days after the sponge implantation, the experimental animal depicts ingrowth of connective tissue. Haematoxylin and eosin. $\times 85$. 
FORMOCRESOL, CONNECTIVE TISSUE AND PROLINE-H ${ }^{3}$ RADIOAUTOGRAPHY

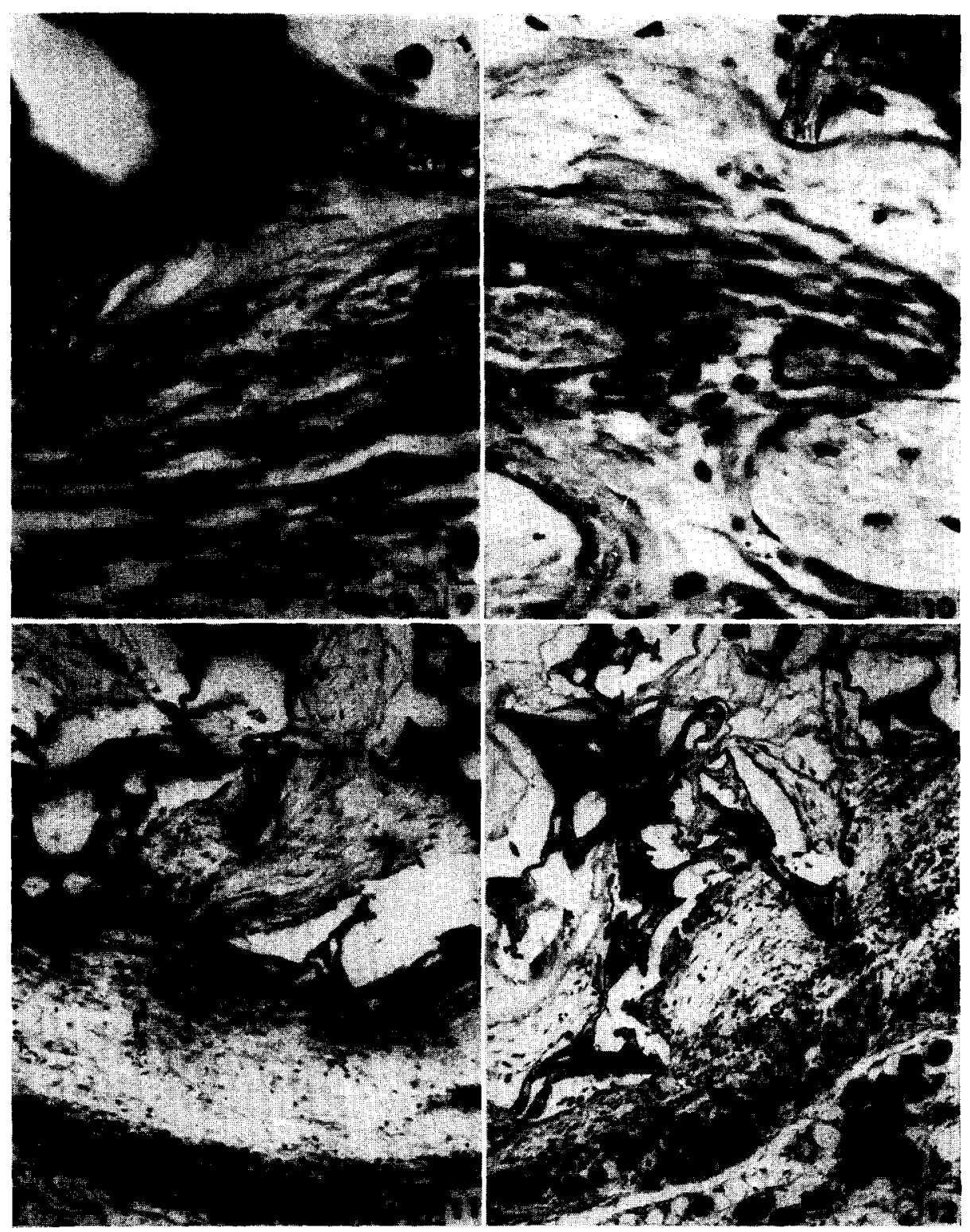

Plate 3

A.O.B. f.p. 286 


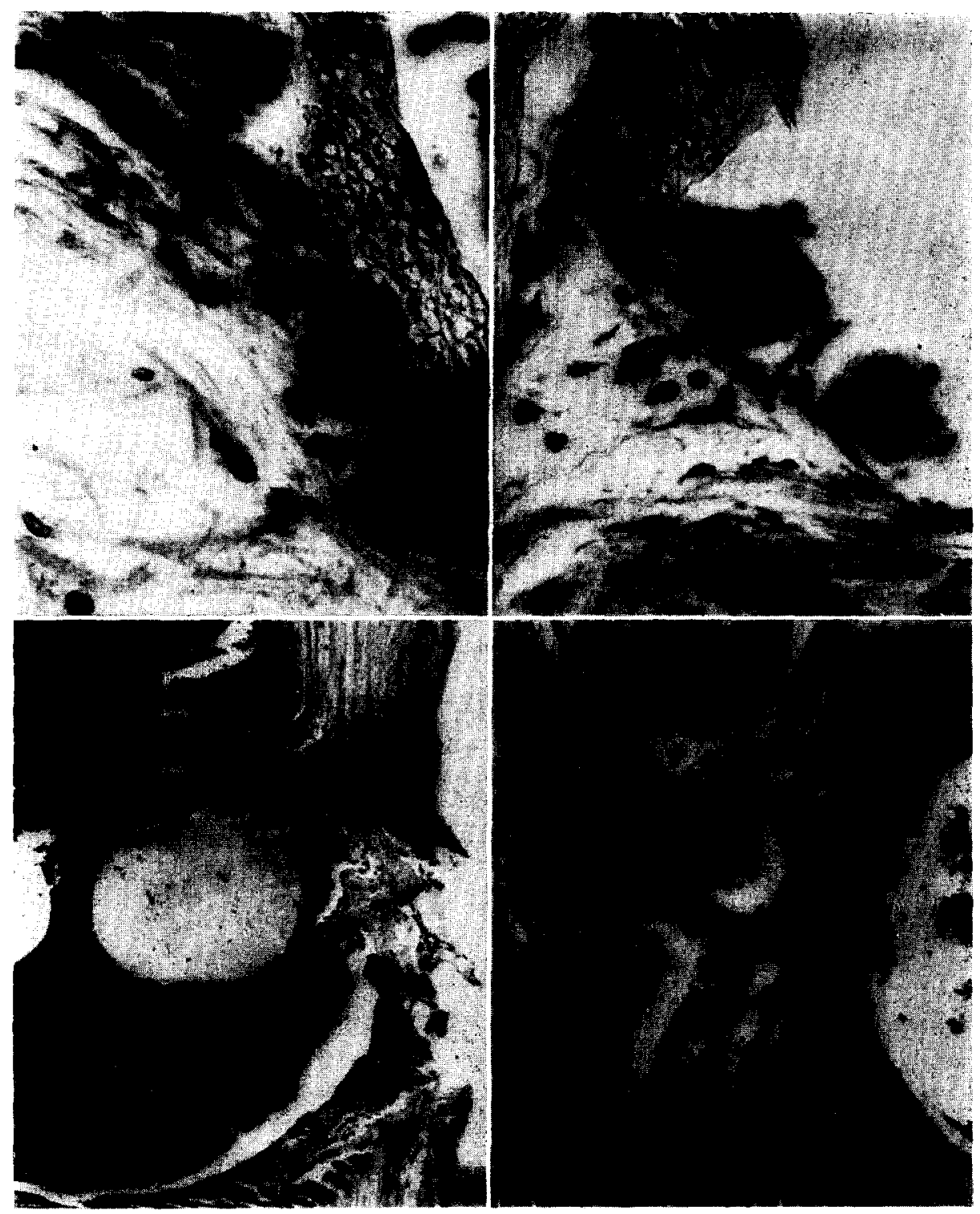




\section{Plate 4}

Fig. 13. The sponge from control animal, 10 days after implantation has giant cells, robust fibroblasts and collagen. Haematoxylin and eosin. $\times 538$.

FIG. 14. The sponge from experimental animal, 10 days after implantation has giant cells, robust fibroblasts and collagen. Haematoxylin and eosin. $\times 538$.

Fig. 15. The femur wound area of the control animal, 10 days after, shows new bone growth. Haematoxylin and eosin. $\times 85$.

Fic. 16. The femur wound area of the experimental animal, 10 days after, depicts new bone growth. Haematoxylin and eosin. $\times 85$. 


\section{Plate 5}

FIG. 17. Radioautograph of 5-hr-sponge implant from the control animal injected with proline- $\mathrm{H}^{3} 4 \mathrm{hr}$ prior to sacrifice. Most fibroblasts are intensely labelled. Haematoxylin and eosin. $\times 602$.

FIG. 18. Radioautograph of 5-hr-sponge implant from the FC-treated animal injected with proline- $\mathrm{H}^{3} 4 \mathrm{hr}$ prior to sacrifice. The number of grains/cell is generally fewer than in Fig. 17, and some cells are not labelled at all. Haematoxylin and eosin. $\times 602$.

FIG. 19. Radioautograph of 3-day-old sponge implant from the control animal injected with proline- $\mathrm{H}^{3} 4 \mathrm{hr}$ prior to sacrifice. Haematoxylin and eosin. $\times 602$.

FIG. 20. Radioautograph of 3-day-old sponge implant from the $\mathrm{HC}$-treated animal injected with proline- $\mathrm{H}^{3} 4 \mathrm{hr}$ prior to sacrifice. Haematoxylin and eosin. $\times 602$.

FIG. 21. Radioautograph of 1-day-old sponge implant from the control animal injected with proline- $\mathrm{H}^{3} 24 \mathrm{hr}$ prior to sacrifice. Haematoxylin and eosin. $\times 602$.

FIG. 22. Radioautograph of 1-day-old sponge implant from the FC-treated injected with proline- $\mathrm{H}^{3} 24 \mathrm{hr}$ prior to sacrifice. Compared to Fig. 21 fewer extracellular grains are seen. Haematoxylin and eosin. $\times 602$.

Fig. 23. Radioautograph of 3-day-old sponge implant from the control animal injected with proline- $\mathrm{H}^{3} 24 \mathrm{hr}$ prior to sacrifice. Notice the large number of extracellular grains. Haematoxylin and eosin. $\times 602$.

Fig. 24. Radioautograph of 3-day-old sponge implant from the FC-treated animal injected with proline- $\mathrm{H}^{3} 24 \mathrm{hr}$ prior to sacrifice. The number of extracellular grains are much fewer than in Fig. 23. Haematoxylin and eosin. $\times 602$.

FIG. 25. Radioautograph of 10-day-old sponge implant from the control animal injected with proline- $\mathrm{H}^{3} 24 \mathrm{hr}$ prior to sacrifice. Haematoxylin and eosin. $\times 602$.

FIG. 26. Radioautograph of 10-day-old sponge implant from the FC-treated animal injected with proline- $\mathrm{H}^{3} 24 \mathrm{hr}$ prior to sacrifice. Extracellular labels appear to be approximately the same as control. Haematoxylin and eosin. $\times 602$. 


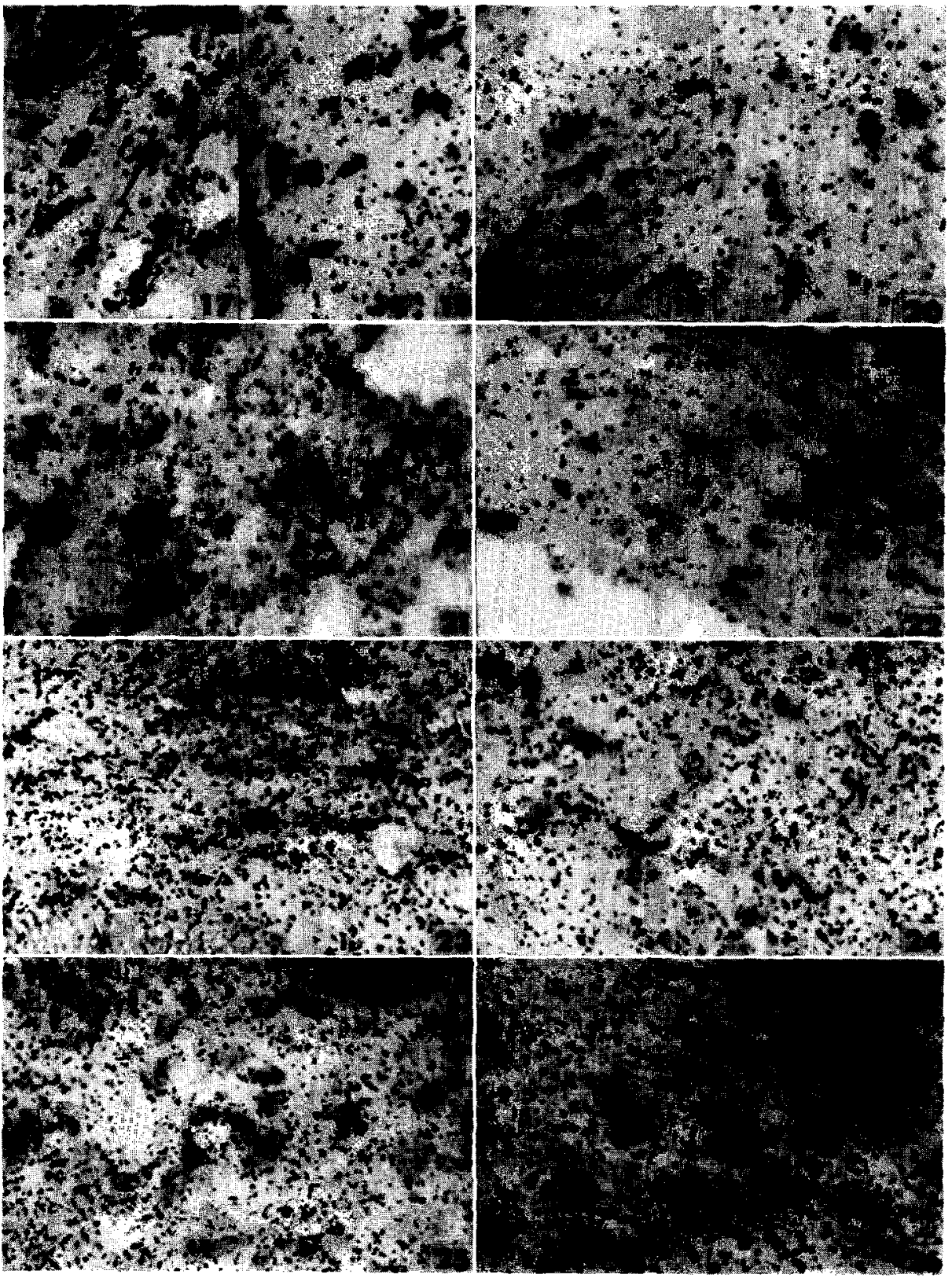

